УДК 553. 98(479.24): 550.8.072

\title{
ПЕРСПЕКТИВЫ НЕФТЕГАЗОНОСНОСТИ АНТИКЛИНАЛЬНОЙ ЗОНЫ ХАЛИ-НЕФТ ДАШЛАРЫ В СВЯЗИ С ЕЁ ПАЛЕОТЕКТОНИЧЕСКИМИ УСЛОВИЯМИ
}

\author{
Мухтарова Хураман Зиядхан гызы1', \\ kmukhtarova.khuraman@mail.ru \\ Насибова Гюльтар Джумшуд гызы 1 , \\ gultar_nasibova_1@yahoo.com \\ 1 Азербайджанский Государственный университет нефти и промышленности,
Азербайджан, AZE1010, г. Баку,пр. Азадлыг, 34.
}

Актуальность. Абшеронский нефртегазоносный район, где были проведены исследования, является одним из продуктивных в Азербайджане. Цель поисково-разведочных работ в основном заключается в увеличении добычи углеводородов, а это достигается выявлением новых нефртегазоносных объектов. С этой точки зрения в антиклинальном поясе Хали-Нефт Дашлары в разрезе палеоген-миоценовых отложений выявление залежей, связанных с антиклинальными и неантиклинальными типами ловушками, имеет важную практическую особенность и это однозначно сыграет немаловажную роль в повышении добычи несрти и газа в республике. Наши исследования были проведены по определяющим нефртегазоносность критериям: геотермическим, литофациальным, тектоническим, палеотектоническим и m. д., по стратиграфрическому разрезу палеоген-миоцен и плиоцена для определения новых объектов.

Цель: определить с геотермической точки зрения в какой зоне нефртегазообразования в настоящее время находятся отложения продуктивной толщи и, в соответствии с этим, уточнить перспективность зоны, а также исследовать распространенность неантиклинальных ловушек в связи с палеотктоническими особенностями и конседиментационным развитием зоны.

Объекты: отдельные структуры, представляющие антиклинальную зону Хали-Нефт Дашлары, свиты нижнего отдела продуктивной толщи.

Методы. Изменения общей мощности и песчанистости отложений продуктивной толщи в исследуемых структурах были проанализированы в локальном и региональном направлениях, были построены соответствующие диаграммы, отражающие закономерности изменения мощности и песчанистости по свитам. Наряду с этим были построены палеопрофили, отражающие палеотектоническое развитие структур антиклинальной зоны Хали-Нефтт Дашлары.

Результаты. Построение графика скорости осадконакопления и, в связи с этим, анализ данных, изучение палеотемпературных условий Пираллахи-Келькорской впадины и проведенный анализ позволяют определить время нахождения отложений как продуктивной толщи, так и нижележащих отложений миоцена, палеогена и мезозоя в главной зоне нефртегазообразования, а также сопоставить главные этапы миграции со временем образования структур в пределах данной территории. Результаты всех исследований, проведенных в этом направлении, позволяют утверждать, что область исследований и ее окрестности также являются перспективными с точки зрения несртегазоносности.

\section{Ключевые слова:}

Мощность, песчанистость, перспективность, зона, структура, отложения, палеопрофиль, продуктивная толща, палеотектоника, несрть, газ.

\section{Введение}

Абшеронский архипелаг с тектонической точки зрения является морским продолжением юго-восточного погружения мегаантиклинориума Большого Кавказа [1].

В морской акватории Абшеронского нефтегазоносного района было обнаружено 19 нефтегазоконденсатных месторождений: Западный Абшерон, Абшерон Кюпеси, Чилов Адасы, Ази Асланов, Палчыг Пильпилеси, Нефт Дашлары, Гюнешли, Чыраг, Азери, Кяпаз, Дарвин Кюпеси, Пираллахи, Гюргян-дениз, Джануб, Джануб-2, Гум-дениз, Бахар, Шах-дениз, 8 Марта [2].

Кроме указанных нефтегазоконденсатных месторождений были обнаружены и подготовлены к глубинному поисково-разведочному бурению еще 13 перспективных структур: Шимали Абшерон, Хазри, Арзу, Дан Улдузу, Ашрефи, Айпара, Хамдам, Гошадаш, Новханы, Гарабах, Сайяр, Саба, Абшерон (рис. 1).

Отложения, присутствующие в геологическом строении участков, относящихся к Абшеронскому архипелагу, охватывают довольно обширный стратиграфический интервал от палеогена до четвертичного периода.
На площадях были пробурены, соответственно, Хали - 15, Чилов адасы - 54, Ази Асланов - 9, Палчыг Пильпилеси - 56 поисково-разведочных скважин. На площади Хали в сважинах 3, 6, 10 отложения продуктивной толщи (ПТ) и подстилающие их отложения представлены глинистой (пелитовой) и песчанистой (псаммитовой) фациями.

Неперспективное с точки зрения нефтегазоносности поднятие Хали является брахиантиклинальной складкой, простирающейся с северо-запада на юговосток, величиной $12,5 \times 4,5$ км. Вдоль оси поднятия проходит крупный продольный разрыв, в результате чего северо-восточное крыло надвинуто на опустившееся юго-западное. Другим продольным разломом юго-западное крыло разделяется на две части, что привело к более опущенному (по сравнению с северовосточным) юго-западному крылу. Кроме этих разрывных нарушений структура осложняется и поперечными разрывами, которые придают складке блоковый характер. Ввиду малого количества пробуренных здесь скважин, небольшого объема проведенных исследований, скудного материала особенности дан- 
ной складки освещены в данной статье невсесторонним образом $[3,4]$.
Структура Чилов адасы имеет то же простирание, что и Хали, с размерами 10×4 км. Складка близка к симметричной, углы залегания в крыльях составляют 55-80 (рис. 2).
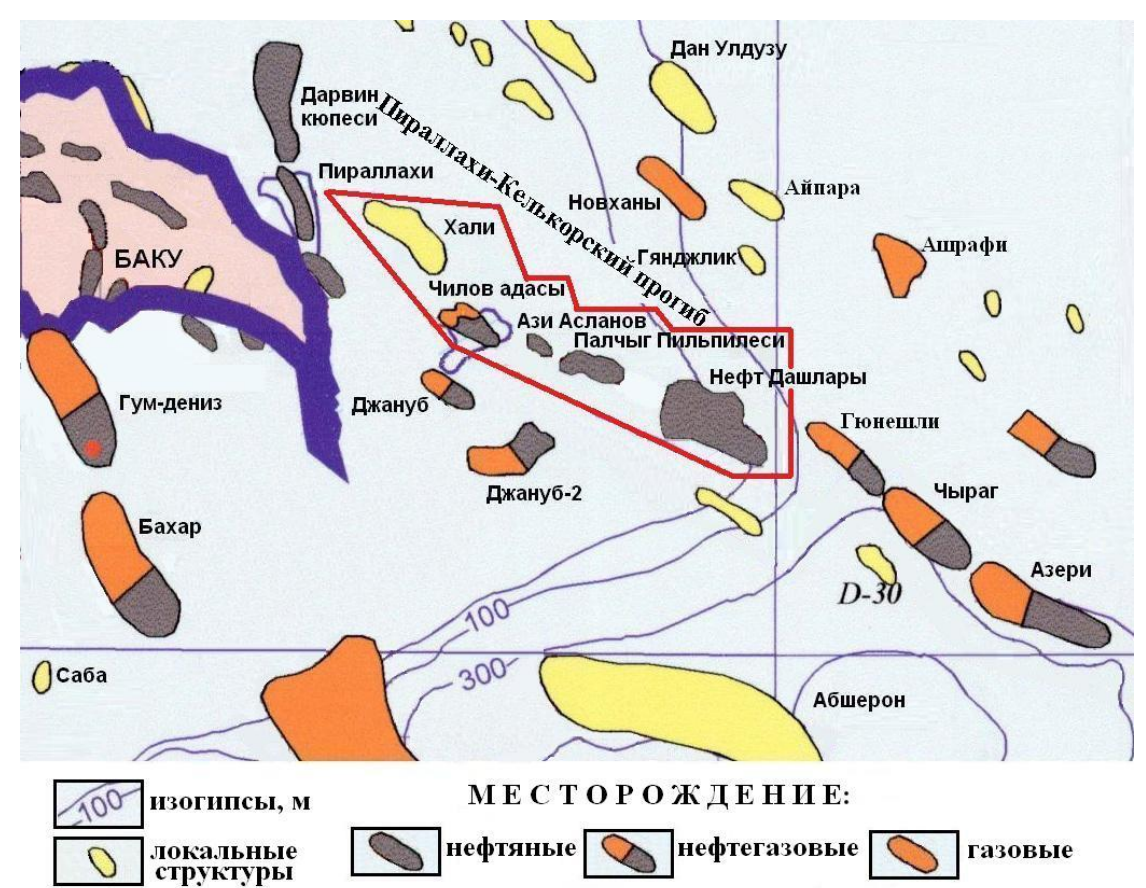

МЕ С ТОРОЖДЕ НИЕ:

Pис. 1. Абшеронский нефтегазоносный район. Обзорная карта

Fig. 1. Absheron oil and gas region. General map
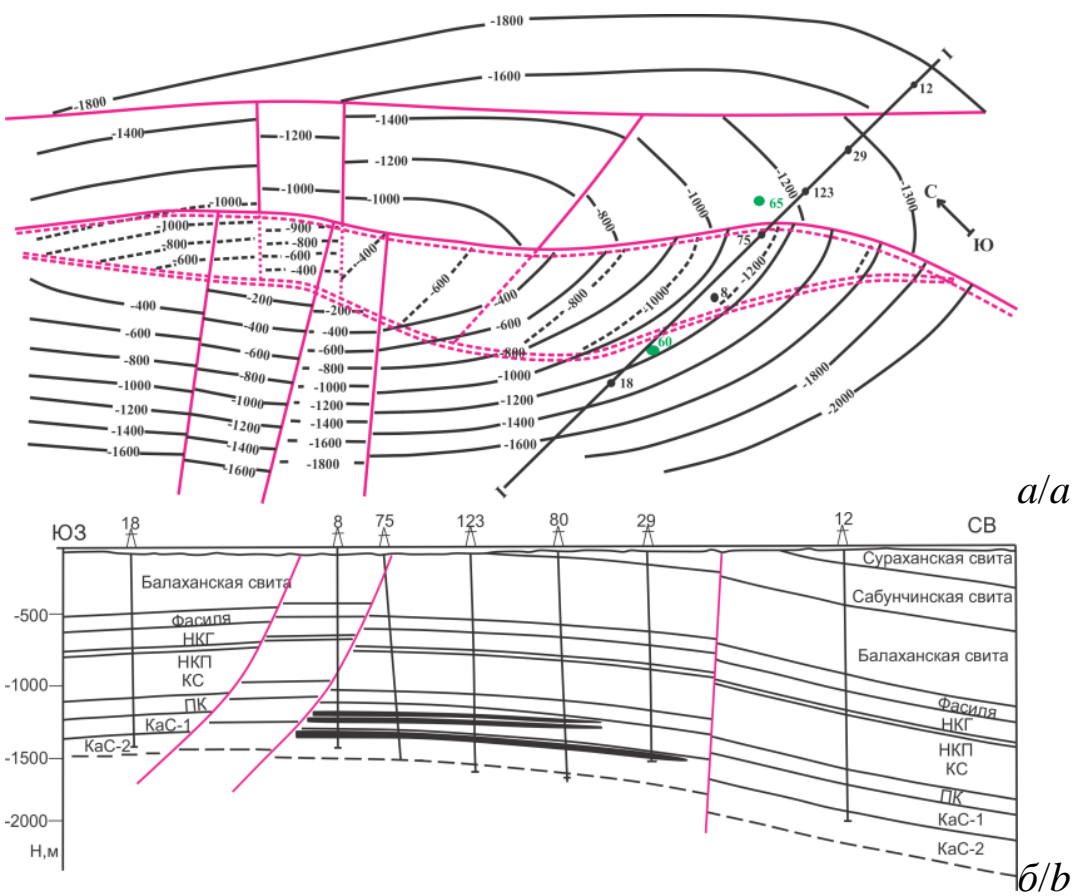

Условные обознатения:

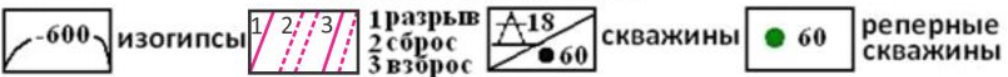

НКТ - надкирмакинская глинистая; НКП - надкирмакинская песчаная; КС-кирмакинская; ПК- подкирмакинская; КаС-калинская

Pис. 2. Месторождение Чилов адасы: а) структурная карта по кровле калинскойсвиты продуктивной толщи (масштаб 1:25000); б) профиль по линии I-I (масштаб 1:10000)

Fig. 2. Chilov adasy oilfield: a) structural map for the top of the Gala suite of the productive series (scale 1:25000); b) cross-section through the line I-I (scale 1:10000) 
Складку осложняют разрывы продольного и поперечного характера. Основные продольные разрывы надвигового типа. Юго-западное крыло надвинуто на северовосточное. Складка расчленена на 10 блоков многочисленными поперечными разрывами амплитудой 250 м.

Структура Ази Асланов, величиной 2,9×1,4 км (рис. 3), с тектонической точки зрения является асимметричной складкой. Присводовая часть и северо-восточное крыло складки осложнены продольными разрывами амплитудой 250 м. Указанные относительно объема имеющегося материала выше данные о площади Хали полностью можно отнести и к структуре Ази Асланов. Несмотря на недостаточность информации, данная структура является более интересной с точки зрения перспектив нефтегазоносности ввиду ее расположения между двумя месторождениями с промышленными запасами углеводородов [5].

С тектонической точки зрения структура Палчыг Пильпилеси (рис. 4) представляет собой брахиантиклинальную складку северо-запад-юго-восточного простирания.
Складка осложнена многочисленными продольными и поперечными разрывами и расчленена на несколько блоков. Складка размерами $9 \times 1$ км расчленена продольными нарушениями на три блока и проявляет себя в виде горста юго-восток-северо-западного направления.

На площади Хали при проведении работ по опробованию и освоению скважины 10 в интервале 9661048 м из калинской свиты $(\mathrm{КаC)} \mathrm{была} \mathrm{получена}$ нефть дебитом 0,5 т/сут $[6,7]$.

На площади Чилов адасы КаС дала нефть в 30 скважинах. На площади Ази Асланова из КаС в скв. 1 во время опробования с интервала 1806-1813 м была получена нефть дебитом 25 т/сут, в скв. 3 с интервала 1902-1923 м - нефть дебитом 18 т/сут, газ 100-150 тыс. м $^{3} /$ сут, в скв. 5 с интервала 1781-1817 м - газ дебитом 2 тыс. м³/сут, в скв. 6 с интервала 1574-1610 м - нефть дебитом 30 т/сут, с интервала 1729-1743 м - нефть дебитом 8-12 т/сут [8, 9].
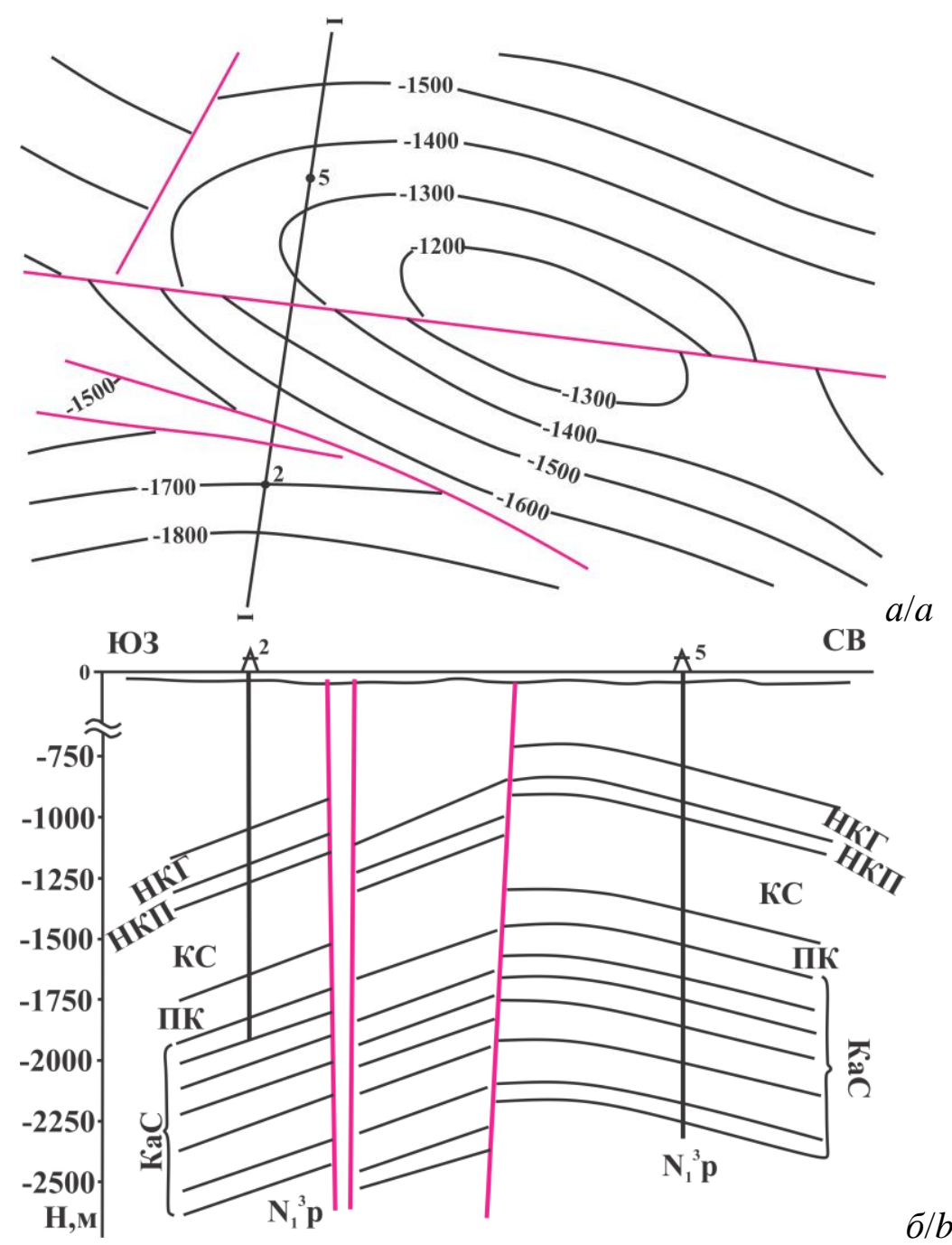

Рис. 3. Месторождение Ази Асланов: а) структурная карта по кровле подкирмакинской свиты продуктивной толщи (масштаб 1:25000); б) профиль по линии I-I (масштаб 1:10000) (Условные обозначения см. на рис. 2)

Fig. 3. Hazi Aslanov oilfield: a) structural map for the top of the Girmakialti suite of the productive series (scale 1:25000); b) cross-section through the line I-I (scale 1:10000) (see legend for Fig. 2) 


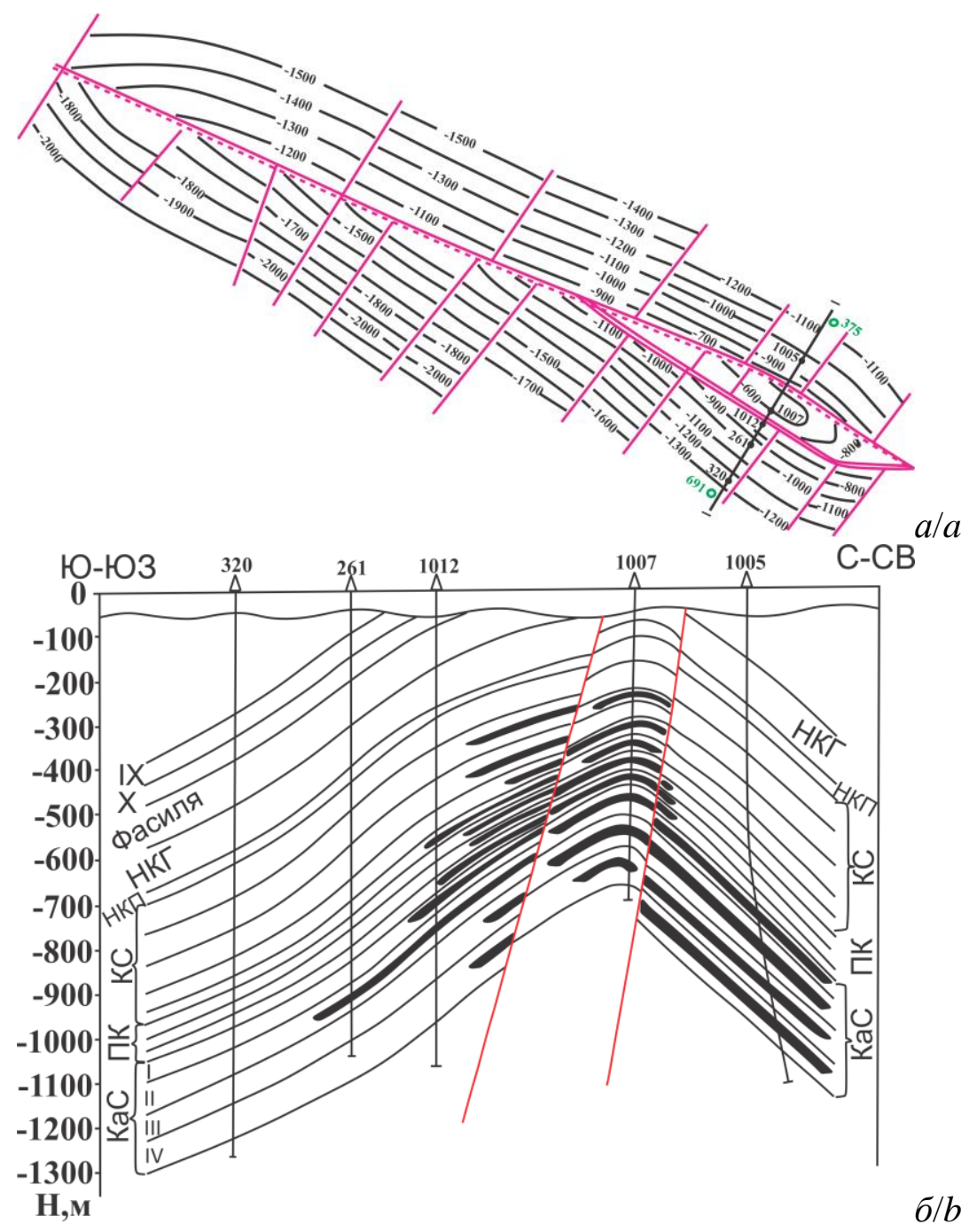

Рис. 4. Месторождение Палчыг Пильпилеси: а) структурная карта по кровле IV горизонта калинской свиты продуктивной толщи (масштаб 1:30000); б) профиль по линии I-I (масштаб 1:15000) (Условные обозначения см. на рuc. 2)

Fig. 4. Palchiq Pilpilesi oilfield: a) Structural map for the top of the horizon IV of the Gala suite of the productive series (scale 1:30000); b) cross-section through the line I-I (scale 1:15000) (see legend for Fig. 2)

На площади Палчыг Пильпилеси из КаС из 46 скважин были получены углеводороды. Надо отметить, что в Абшеронской зоне все разведанные месторождения нефти и газа связаны с плиоценовыми отложениями. В целом подверженность площадей Пираллахи, Гюргян-дениз, Хали, Чилов адасы, Джануб, Ази Асланов, Палчыг Пильпилеси воздыманию в определенные периоды времени, в особенности к концу нижнего плиоцена, способствовала либо частичному, либо же полному вымыванию отложений верхней ПТ, а также повлияло на изменение их литологического состава, привело к выклиниванию ряда пластов. Вышеописанные процессы оказали прямое либо косвенное влияние на формирование ловушек неантиклинального типа, привели к определенным ограничениям с точки зрения перспектив нефтегазоносности, которые в данных структурах связаны с нижним отделом ПТ, а если точнее, с отложениями кирмакинской свиты (КС), подкирмакинской свиты (ПК) и $\mathrm{KaC}[10]$.

\section{Методы}

Были рассмотрены данные кернов из 69 скважин, которые содействовали попыткам проследить песчанистость и мощность горизонтов и свит ПТ.

Исследования были проведены для всех структур. Было изучено изменение общей мощности и песчанистости осадков ПТ как по площади, так и в региональном масштабе.

Средняя мощность надкирмакинской песчанистой (НКП) свиты на структуре Чилов адасы в 34 м, на Ази Асланов - 38 м, Палчыг Пильпилеси - 39 м и на Нефт Дашлары - 46 м указывает на более интенсивное осадконакопление в юго-восточном направлении (табл. 1). Средние показатели песчанистости данных отложений в $24 \%$ для площади Ази Асланов, $39 \%$ для Чилов адасы, 94 \% - для Нефт Дашлары и $19 \%$ для Палчыг Пильпилеси позволяют высказать предположение о том, что по всей зоне структура Палчыг Пильпилеси в данный век являлась наиболее глубоководным участком бассейна (табл. 2). 
На основе средних значений табл. 1, 2 были построены диаграммы изменения мощности (рис. 5) и песчанистости (рис. 6) для четырех свит ПТ по отдельности для всей антиклинальной зоны Чилов адасы-Нефт Дашлары, которые были использованы при определении там, где это возможно, закономерностей во взамоотношениях мощности и песчанистости этих же свит.

Таблица 1. Средние значения мощностей отдельных свит продуктивной толщи антиклинальной зоны Чилов адасы-Нефт Дашлары

Table 1. Average thickness values for the individual productive series suites of the Chilov adasiNeft Dashlari anticline zone

\begin{tabular}{|l|c|c|c|c|}
\hline \multirow{2}{*}{ Структуры/Structures } & \multicolumn{4}{|c|}{$\begin{array}{c}\text { Средние значения мощностей } \\
\text { отдельных свит ПТ } \\
\text { Average thickness values } \\
\text { for individual PS suites }\end{array}$} \\
\cline { 2 - 6 } & HКП/NKP & КС/KS & ПК/PK & КаC/KaS \\
\hline Чилов адасы/Chilov adasi & 34 & 287 & 90 & 433 \\
\hline Ази Асланов/Azi Aslanov & 38 & 364 & 92 & 606 \\
\hline $\begin{array}{l}\text { Палчыг Пильпилеси } \\
\text { Рalchig Pilpilesi }\end{array}$ & 39 & 273 & 117 & 411 \\
\hline $\begin{array}{l}\text { Hефт Дашлары } \\
\text { Neft Dashlari }\end{array}$ & 46 & 298 & 80 & 170 \\
\hline
\end{tabular}

Таблица 2. Средние значения песчанистости отдельных свит продуктивной толщии антиклинальной зонь Чилов адасы-Нефт Дашлары

Table 2. Average sandiness values for the individual Productive Series suites of the Chilov adasiNeft Dashlari anticline zone

\begin{tabular}{|c|c|c|c|c|}
\hline \multirow[t]{2}{*}{ Структуры/Structures } & \multicolumn{4}{|c|}{$\begin{array}{c}\text { Средние значения песчанистость } \\
\text { отдельных свит ПТ } \\
\text { Average sandiness values for individual } \\
\text { PS suites }\end{array}$} \\
\hline & НКП/NKP & $\mathrm{KC} / \mathrm{KS}$ & ПК/PК & $\mathrm{KaC} / \mathrm{KaS}$ \\
\hline Чилов адасы/Chilovadasi & 39 & 6 & 46 & 28 \\
\hline $\begin{array}{l}\text { Ази Асланов } \\
\text { Azi Aslanov }\end{array}$ & 24 & 3 & 35 & 29 \\
\hline \begin{tabular}{|l|} 
Палчыг Пильпилеси \\
Palchig Pilpilesi
\end{tabular} & 19 & 10 & 32 & 31 \\
\hline $\begin{array}{l}\text { Нефт Дашлары } \\
\text { Neft Dashlari }\end{array}$ & 94 & 3 & 45 & 22 \\
\hline
\end{tabular}

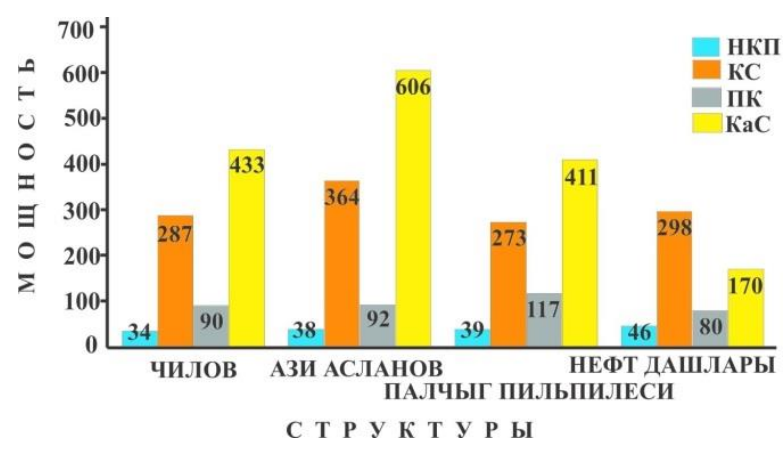

Pис. 5. Диаграмма изменения средних значений мощностей отдельных свит продуктивной толщии антиклинальной зонь Чилов адасы-Нефт Дашлары

Fig. 5. Chart of the average thickness values variation for individual productive series suites of the Chilov adasi-Neft Dashlari anticline zone

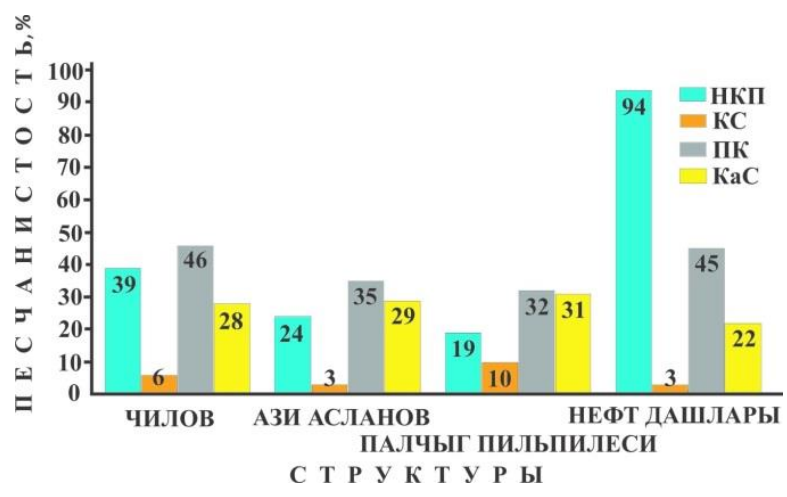

Pис. 6. Диаграмма изменения средних значений песчанистости отдельных свит продуктивной толщи антиклинальной зоны Чилов адасы-Нефт Дашлары

Fig. 6. Chart of the average sandiness values variation for individual productive series suites of the Chilov adasi-Neft Dashlari anticline zone

Средняя мощность свиты КС, в разы превосходящая таковую НКП, при максимальном значении 364 м на площади Ази Асланов составляет 287 м на Чилов адасы, 273 м - на Палчыг Пильпилеси, 298 м - Нефт Дашлары, а песчанистость - в несколько раз меньше, т. е. изменяется в пределах 3-10\% (учитываются средние значения песчанистости отдельных структур), что дает возможность прийти к выводу о том, что в данный промежуток времени дно бассейна располагалось на относительно большей глубине. Следует отметить, что мощность КС в 364 м на структуре Ази Асланов антиклинальной зоны, а песчанистость в $10 \%$ на площади Палчыг Пильпилеси, будучи максимальными, уменьшаются как в северо-западном, так и в юго-восточном направлениях. Значения песчанистости на участках Ази Асланов и Нефт Дашлары составили $3 \%$, а на Чилов адасы - $6 \%$.

Минимальное значение средней мощности свиты ПК в 80 м наблюдается на структуре Нефт Дашлары, а максимальное - 117 м - на Палчыг Пильпилеси (Ази Асланов - 92 м, Чилов адасы - 90 м). Мощность данной свиты в пределах антиклинальной зоны падает от участка Палчыг Пильпилеси как в северозападном, так и в юго-восточном направлениях. Песчанистость составляет $46 \%$ на Чилов адасы, $45 \%$ на Нефт Дашлары, 25 \% - на структуре Ази Асланов и $32 \%$ - на Палчыг Пильпилеси. Таким образом, мощность и песчанистость на площади Палчыг Пильпилеси характеризуются обратной пропорциональной зависимостью, вдоль антиклинальной зоны Чилов адасы - Ази Асланов - Палчыг Пильпилеси - Нефт Дашлары наблюдается почти симмметричное изменение песчанистости (ее уменьшение к центральной части). Вышеуказанные данные указывают на отсутствие закономерности между песчанистостью и мощностью.

Мошность отложений КаС свиты достигают максимального значения в 606 м на структуре Ази Асланов, от которой отмечается ее сокращение как в северо-западном, так и в юго-восточном направлениях (на Чилов адасы - 433 м, Палчыг Пильпилеси - 411 м, 
Нефт Дашлары - 170 м). Максимальная песчанистость этих же отложений при значении 31 \% наблюдается на структуре Палчыг Пильпилеси. Песчанистость падает от данной площади в северо-западном направлении к структурам Ази Асланов и Чилов адасы, составляя 28-29\%, а также к юго-востоку, в сторону Нефт Дашлары, со значением $22 \%$.

Проведенные исследования показывают, что свиты КС и КаС характеризуются большой мощностью, а свиты НКП и ПК - высокой песчанистостью.

Увеличение мощности (взяв структуру Ази Асланов в качестве точки отсчета) в северо-западном и в юго-восточном направлениях связано со структурнотектоническим развитием антиклинальной зоны. Вышеуказанные закономерности наблюдаются ввиду того, что указанная антиклинальная зона сформировалась на оси Абшероно-Прибалханского структурного мегаседла.

Нами также были рассмотрены перспективы нефтегазоносности антиклинальной зоны Хали-Нефт Дашлары в связи с особенностями палеоразвития локальных структур этой зоны [11-13].

Поднятия этой зоны в основном относятся к структурам диапирового типа, которые были осложнены грязевым вулканизмом - показателем перспектив нефтегазоносности [14-16].

$\mathrm{C}$ целью определения времени образования и изучения особенностей дальнейшего развития поднятий Чилов адасы и Палчыг Пильпилеси были построены и проанализированы палеопрофили верхнего и нижнего отделов ПТ, а также конца позднего плиоцена.

\section{Обсуждение}

По палеопрофилю для конца нижнего отдела ПТ было выявлено, что структура Чилов адасы начала свое формирование не позднее плиоцена, и даже к этому времени была осложнена двумя тектоническими нарушениями [17]. Наличие именно этих нарушений дают основание для предположения более раннего заложения формирования структуры. Уменьшение мощности отложений нижнего отдела ПТ к сводовой части структуры доказывает, что развитие складки происходило одновременно с осадконакоплением, но скорость осадконакопления уступала ему.

По палеопрофилю, построенному к концу второго полувека ПТ (верхний отдел), видно, что, несмотря на заложение ещё двух тектонических нарушений, общий темп развития складки в данный промежуток времени не превышал таковой нижнего отдела.

Палеопрофиль, построенный к концу Акчагильского века, дает возможность утверждать, что в данный век развитие структуры происходило относительно менее интенсивными темпами в сравнении с предыдущим геологическим промежутком времени. Анализируя палеопрофили, построенные для отдельных промежутков геологического времени, следует отметить, что поднятие Чилов адасы развивалось в виде диапира с глинистым ядром и имеет коседиментационный характер. В четвертичный век поднятие Чилов адасы развивалось чрезвычайно интенсивно (рис. 7).
Из палеопрофиля, построенного к концу нижнего отдела ПТ для структуры Палчыг Пильптляси, выясняется, что формирование и развитие этого поднятия началось не позднее плиоцена. Развиваясь структура одновременно осложнялась разрывным нарушением. Вероятно, этот разрыв в начале века ПТ (в нижнем) «омолаживался», а это дает возможность считать, что структура была сформирована до плиоцена. Омоложение разрыва в нижнем полувеке ПТ доказывает, что образование этой складки совпадало одновременно с осадконакоплением. Но в верхнем полувеке ПТ скорость развития осадконакопления отставала от раннего полувека ПТ. По палеопрофилю, построенному для конца абшеронского века, можно сказать, что скорость развития складкообразования относительно верхнему полувеку ПТ была высокой.

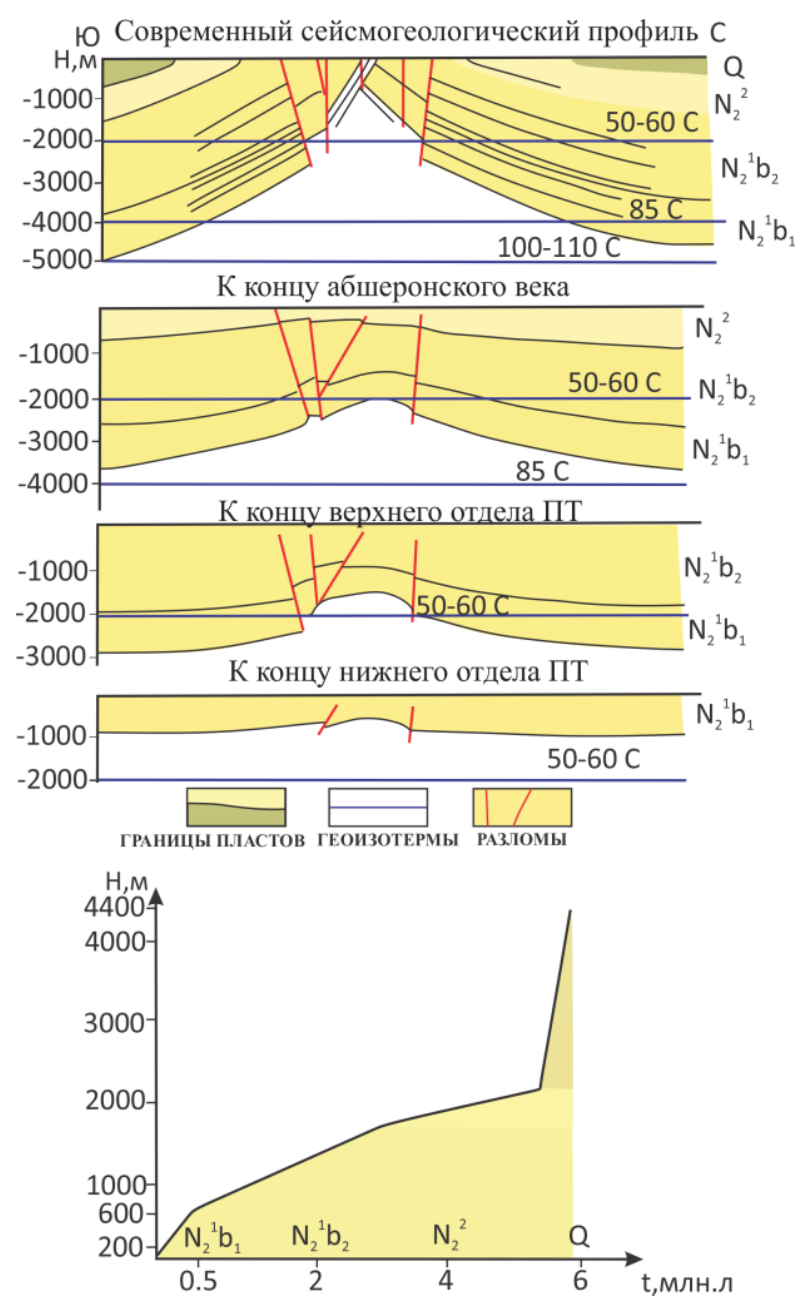

Рис. 7. Палеопрофили и график интенсивности развитияподнятия Чилов адасы

Fig. 7. Paleoprofiles and evolution intensity graph of the Chilov adasy uplift

В позднем плиоцене скорость осадконакопления была выше, чем скорость развития складки, как и в предедущем полувеке.

Таким образом, можно сделать вывод о том, что поднятие Палчыг Пильпилеси, относящееся к диапи- 
ровому типу структуры в рассматриваемом геологическом времени, имело конседиментационный характер развития. Надо отметить, что в четвертичный век развитие этой структуры характеризуется большой интенсивностью. Об этом свидетельствует и тот факт, что если до четвертичного века высота складки достигала 1050 м, то только в период этого века ее высота прибавилась на 1300 м, и в результате этого складка была еще более осложнена нарушениями тектонического характера и ее сводовая часть была смыта еще более. Из графика развития интенсивности складки выясняется, что скорость развития складки со временем усиливалась и именно в четвертичном веке складкообразование на этой территории достигло самой большой интенсивности развития (рис. 8).

Поднятия Чилов адасы и Палчыг Пильпилеси, которые относятся к северной части Абшеронского архипелага, сформировались в южной части ПираллахиКелькорской впадины на тектонической зоне ХалиНефт Дашлары $[15,17]$. На палеопрофилях, построенных к концу нижней ПТ (ранней), явно наблюдается, что эти складки начинали формироваться не позднее раннего плиоцена, а по некоторым фактам в миоцене. Это можно утверждать по соображениям того, что в ЮКВ в кайнозойских отложениях реалогически активные тела, т. е. не томпонированные глины (вещества - кутля), играют непосредственную роль в формировании диапировых структур и имеют именно олигоцен-миоценовый возраст.

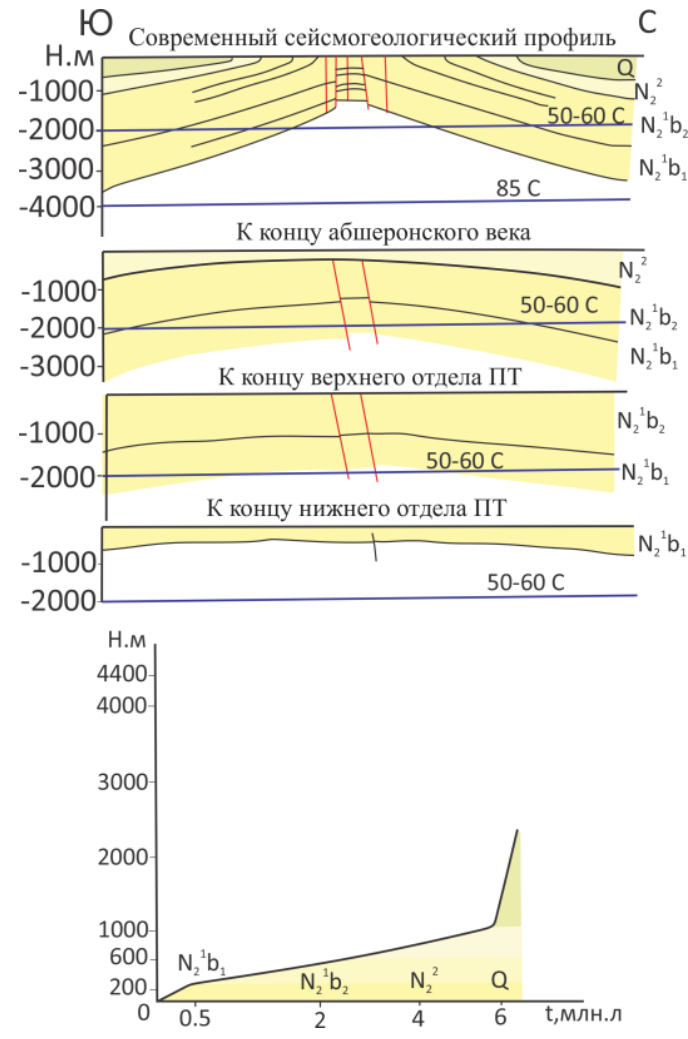

Рис. 8. Палеопрофили и график интенсивности развития поднятия Палчыг Пильпилеси (условные обозначения см. рис. 7)

Fig. 8. Paleoprofiles and the evolution intensity graph of the Palchig Pilpilesi uplift (see legend for Fig. 7)
Проведенный анализ дает возможность прийти к выводам о том, что в рассматриваемый геологический период антиклинальные складки Чилов адасы и Палчыг Пильпилеси, несмотря на различную интенсивность развития, эволюционировали как диапировые складки и характеризуются конседиментационным режимом. Конседиментационное развитие этих поднятий способствует развитию в их пределах ловушек неантиклинального типа, связанных с выклиниванием или же с литофациальным изменением пород в крыльевых частях структур [18].

Как известно, в седиментационном бассейне основная стадия миграции УВ начинается именно тогда, когда потенциальные нефтематеринские пласты входят в главную нефтепораждающую зону и этим превращаются в нефтепораждающий пласт. Надо отметить, что осадки возраста плиоцен-четвертичного века антиклинальной зоны Хали-Палчыг Пильпилеси имели благоприятные условия для накопления и сохранности в них ОВ. Именно здесь по условиям палеотемпературного режима можно определить несколько главных стадий миграции УВ. Для более детального решения этого вопроса нами были построены на основе современного сейсмического профиля палеопрофили для нижнего и верхнего отделов ПТ, и к концу абшеронского века. Кроме этого, выявлены палеотемпературные условия этих стратиграфических единиц. Основываясь на результатах исследований других ученных и по данным отдельных скважин нами проведена палеогеотемпературная линия в палеопрофилях Чилов адасы и Палчыг Пильпиляси (рис. 7, 8) $[15,19,20]$.

По данным палеореконструкций, проведенных на основе построенных палеопрофилей, где обозначены границы палеоизотерм, можно прийти к выводу о том, что осадки нижней ПТ находятся в зоне протокатагенеза [15].

По данным графических материалов, т. е. палеопрофилей и палеоизотерм (рис. 7, 8), построенных для осадков верхней ПТ, утверждают, что большая часть отложений нижней ПТ в результате погружения находится в интервале 2000-3000 м; эта зона характеризуется как главная зона нефтепорождения (ГЗН). По палеопрофилям и палеоизотермам, построенным для конца абшеронского века, выясняется, что осадки нижней ПТ полностью, а верхней ПТ частично (относительно малая часть) погружены в ГЗН, которая находится на глубине 2000-4000 м.

Современное положение геоизотермов поднятий Чилов адасы и Палчыг Пильпилеси было определено по температурным данным, взятым из скважин № 375, 691 площади Чилов адасы и скважин № 60, 65 площади Палчыг Пильпилеси, а также по расчетам, основанным на исследовательских работах ряда ученых. Из-за нехватки сведений, касающихся именно изучаемой зоны, нами были использованы данные по территории впадины Пираллахи-Келькор, в пределах которой сформировалась антиклинальная зона ХалиНефт Дашлары $[15,19]$.

По литолого-стратиграфическому разрезу изучаемой территории можно прийти к выводам о том, что 
на данной территории начиная с юрской эпохи до современного геологического времени осадконакопление происходило в бассейнах, имеющих различные глубины. Надо отметить, что осадконакопление происходило в довольно благоприятных с литофациальной точки зрения условиях для накопления и сохранения ОВ и по этой причине каждый литофациальный комплекс можно рассматривать как потенциально нефтематеринский.

В этом бассейне от юры до позднего мела средняя скорость осадконакоплении составляла 124 м/млн лет (рис. 9). Такой показатель скорости осадконакопления свойственен нефтегазоносным бассейнам с высокой активностью. Исследования ученых показали, что в осадках при скорости в 130 м/млн лет может накопиться до $2 \%$ органического вещества (OB) [10].

Как было отмечено ранее, в стратиграфическом интервале от верхнего мела до нижнего плиоцена средняя скорость осадконакопления была равна 30 м/млн лет. При данных палеогеографических условиях в осадках этого возраста могло быть накоплено лишь 0,3 \% ОВ [10], и поэтому сложно предположить наличие нефтематеринских пород в данном стратиграфическом интервале.

В интервале нижний плиоцен-четвертичный век средняя скорость осадконакопления составляла 770 м/млн лет, что свидетельствует о наличии благоприятных условий для накопления достаточного количества ОВ в осадках. Как известно, в присутствии других положительных факторов, при скорости осадконакопления, превышающей 660 м/млн лет, в осадочных комплексах бассейнов могло, предположительно, накопиться до 11-18 \% ОВ.

Проведенные исследования дают возможность прийти к выводам о том, что в стратиграфическом интервале юра-ранний мел и ранний плиоценчетвертичный век на изучаемой территории существовали наиболее благоприятные условия для накопления и сохранения OB.

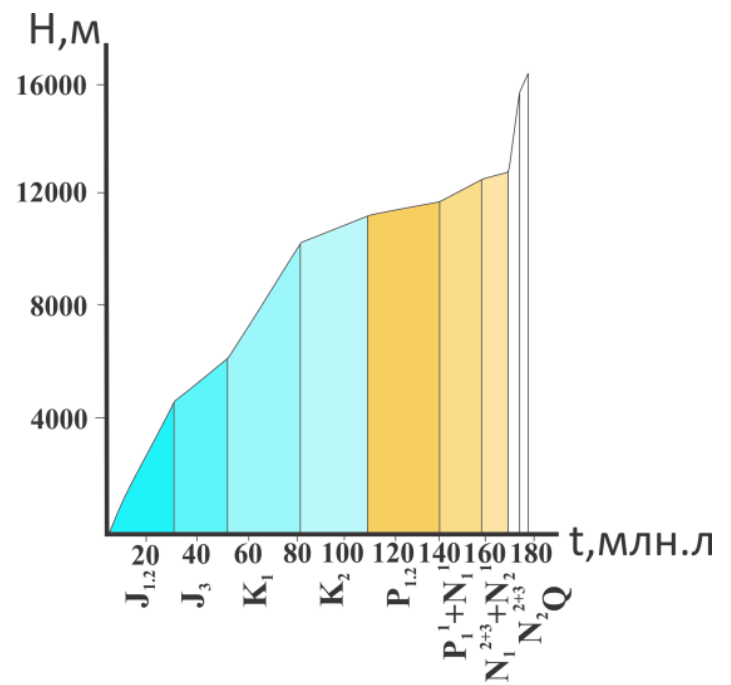

Рис. 9. График скорости осадконакопления в Пираллахи-Келькорской впадине

Fig. 9. Deposition rate diagram for the Pirallahi-Kelkor depression
Изучая геотермическую обстановку бассейна, можно определить глубины температурных интервалов, соответствующих основным зонам нефтегазообразования. Таким образом, данный анализ позволяет определить, в какой зоне в настоящее время находится каждый потенциальный нефтематеринский пласт [15].

Ввиду того, что построенные на основе современных сейсмогеологических профилей палеопрофили не охватывают обширный стратиграфический интервал времени, в целях более детального анализа основных этапов миграции углеводородов (УВ) были использованы научные работы в области ПираллахиКелькорской впадины, где расположена антиклинальная зона Хали-Чилов-Палчыг Пильпилеси [10, 15, $16]$.

На основе данных глубокого бурения в Пираллахи-Келькорской впадине было установлено, что осадочный чехол в пределах территории исследований был изучен вплоть до нижнего мела. Более глубокие части разреза (юрские отложения) были описаны на основании данных сопредельных территорий.

Для изучения более глубоких частей разреза на основании сейсмогеологического профиля, проходящего перпендикулярно простиранию ПираллахиКелькорской впадины, были построены палеотектонические профили для юры, нижнего мела, миоцена и конца плиоцена. Кроме этого, к концу каждого из вышеуказанных стратиграфических единиц были установлены палеотемпературные условия суббассейна $[20,21]$.

Согласно палеопрофилю конца юрского периода наблюдается глубина залегания кристаллического фундамента в 6000 м и погружение юрских отложений с 1000 до 4000 м в пределы главной зоны нефтеобразования (ГЗН).

В конце нижнего мела верхняя часть юры и большая часть нижнего мела находятся в ГЗН. В это время основная масса юрских отложений вошла в главную зону газообразования (ГЗГ).

В конце миоцена в ГЗН находилась основная часть меловых, а в ГЗГ больше половины юрских и нижняя часть меловых отложений. В конце плиоцена вторая половина юрских и большая часть нижнемеловых отложений вошли в ГЗГ, а верхняя часть нижнемеловых и плиоценовые отложения перешли в ГЗН.

Так как Пираллахи-Келькорская впадина была многоочаговым суббассейном, в процессе своего развития она охватывала несколько главных этапов миграции УВ. Несмотря на то, что эти миграционные этапы происходили в разные геологические времена (относительно молодые стратиграфические комплексы погребали более древние), они последовательно сменяли друг друга [15].

Так, например, к концу нижнего мела большая часть отложений накопилась на отложениях юры, тогда как юрские отложения, находясь в ГЗН, не покинули эту зону. Это свидетельствует о том, что в конце нижнего мела главный этап миграции УВ соответствовал отложениям юры и первой половины нижнего мела. 
В конце миоцена отложения верхнего мела и палеогена, содержащие в достаточном количестве ОВ, погрузились в ГЗН. Это указывает на то, что в конце миоцена главный этап миграции охватывал нижний и верхний мел и первую половину палеогена. В конце плиоцена отложения верхней половины нижнего мела и нижнего плиоцена находились в ГЗН и отложения нижнего мела и нижнего плиоцена находились в главной зоне миграции УВ. Наконец, в настоящее время в ГЗН находятся отложения от верхов нижнего мела до низов верхнего плиоцена. Как видно, главный этап миграции охватывает отложения нижнего мела и нижнего плиоцена [15].

По данным сейсмологии можно прийти к выводу о том, что до периода формирования складок Чилов адасы и Палчыг Пильпилеси нефтематеринские породы нижней части юрских и меловых отложений уже вошли в ГЗГ, пройдя зону ГЗН не позднее конца миоцена или же начала раннего плиоцена. Результаты исследований дают возможность утверждать, что майкопская серия вошла в ГЗН несколько позже и данная ситуация соответсвует геологическому времени, когда вышеназванные локальные поднятия уже были сформированы.

Весь вышеописанный анализ дает основание утверждать, что площадь Ази Асланов, расположенная среди исследуемых структур, а также расположенная к северо-западу от структуры Чилов адасы, т. е. в начале зоны, и площадь Хали могут считаться перспективными.

\section{Результаты}

Таким образом, можно утверждать, что главный этап миграции УВ, порожденных отложениями майкопской серии, имел место после формирования локальных поднятий, что позволяет предполагать высокие перспективы нефтегазоносности этих структур

Если учесть, что формирование рассматриваемых локальных поднятий произошло не позднее, и даже ранее, миоценовой эпохи, можно сказать, что их природные резервуары могут быть насыщены УВ, образованными в отложениях мелового, палеогенового и нижнеплиоценового возраста. Ввиду того, что до четвертичного века интенсивность развития складок отставала от скорости осадконакопления, такая ситуация создавала благоприятные условия для сохранения УВ, насыщающих ловушки.

Однако отложения ПТ не полностью вошли в ГЗН и не полностью реализовали свой нефтепродуцирующий потенциал. Данные отложения, лишь частично присутствуя в ГЗН, не всецело участвуют в процессе нефтепорождения.

\section{СПИСОК ЛИТЕРАТУРЫ}

1. Зоненшайн Л.П., Кузьмин М.И., Натапов Л.М. Тектоника литосферных плит территории СССР. - М.: Недра, 1990. $328 \mathrm{c}$

2. Narimanov A.A. Concept on the formation of the oil and gas fields in the South Caspian Basin // Transaction of the İnternational Academy of Science. - 2005-2006. - V. 2. - P. 483-499.
Таким образом, как о Хали-Палчыг Пильпилеси, так и о других исследуемых месторождениях Пираллахи-Келькорской впадины можно высказать мнение о том, что скопившиеся в ловушках в разных фазовых состояниях УВ сформировались благодаря нефтепродуцирующему потенциалу отложений, в основном юры, раннего мела и палеогена.

\section{Выводы}

По геолого-геофизическим данным антиклинальной зоны Чилов адасы-Нефт Дашлары и согласно изучению истории геологического развития, а также анализов, проведенных в результате палеотемпературного, литофациального моделирования, можно прийти к выводам:

1. В результате сравнительного анализа мощностей и песчанистости площадей было определено, что по антиклинальной зоне песчанистость увеличивается в юго-восточном направлении.

2. Локальные поднятия исследуемой антиклинальной зоны конседиментационного происхождения, их формирование началось не позднее миоцена и до четвертичного века скорость их развития уступала скорости осадконакопления. Темпы развития локальных поднятий в четвертичном веке существенно увеличились, что привело к размытию сводовых частей структур, частичному разрушению и повторному формированию УВ залежей.

3. Конседиментационное развитие поднятий исследуемой антиклинальной зоны способствует развитию в их пределах ловушек неантиклинального типа, связанных с выклиниванием или же с литофациальным изменением пород в крыльевых частях структур.

4. До того, как сформировались поднятия Чилов адасы и Палчыг Пильпилеси, нефтематеринские породы низов юры и нижнего мела уже вошли в ГЗГ, пройдя зону ГЗН не позднее конца миоцена или же с начала раннего плиоцена. Майкопская серия вошла в ГЗН несколько позже, и данная ситуация соответсвует геологическому времени, когда вышеназванные локальные поднятия уже были сформированы. Главный этап миграции УВ, порожденных отложениями майкопской серии, имел место после формирования локальных поднятий, что позволяет предполагать высокие перспективы нефтегазоносности этих структур.

5. Вышеописанный анализ дает основание утверждать, что площадь Ази Асланов, расположенная среди исследуемых структур, а также к северозападу от структуры Чилов адасы, т. е. в начале зоны, и площадь Хали могут считаться перспективными.

3. Мухтарова Х.З., Насибова Г.Д. Перспективы нефтегазоносности возможных залежей нестандартного типа (литологически ограниченного) антиклинального пояса Хали-Кяпаз в связи с его историей геологического развития // Геология, геофизика и разработка нефтяных и газовых месторождений. - 2018. № $10 .-$ C. $8-20$.

4. Рахманов И.П. Грязевые вулканы и их значение в прогнозировании нефтегазоносности недр. - М.: Недра, 1987. - 271 с. 
5. Мухтарова Х.З., Насибова Г.Д. Перспективные нефтегазоносные структуры Абшеронского архипелага ЮКВ и основные направления их дальнейших исследований // International Scientifec and Practical Conference: Worldscience. - Abu-Dhabi, UAE, August, 2016. - P. 32-39.

6. Mukhtarova K.Z., Nəsibova G.C. Oil and gas content perspectives of potential non-standard pool types (lithologically confined) of Khali-Kapaz anticlinal belt in connection with its geological development history // National Science Review. - December 2017. - V. 4. - Iss. 4. - P. 1397-1416.

7. Hydrocarbon systems of the South Caspian basin / I.S. Guliyev, P.Z. Mamedov, A.A. Feyzullayev, D.A. Huseynov, F.A. Kadirov, E.H. Aliyeva, M.F. Tagiyev. - Baku: Nafta-Press, 2003. - 206 p.

8. Мухарова Х.З., Насибова Г.Д. Палеотектонические условия формирования структур в Южно-Каспийской впадине и перспективы нефтегазоносности ловушек неантиклинального типа // «Геолог Азербайджана». Научный бюллетень Азербайджанского Общества Нефтяных Геологов. - 2017. - № 21. C. $82-93$.

9. Feyzullayev A.A., Guliyev İ.S., Tagiyev M.F. Source potential of the Mesozoic-Cenozoic rocks in the South Caspian Basin and their role in forming the oil accumulations in the Lower Pliocene reservoirs // Petroleum Geoscience. - 2001. - V. 7 (4). - P. 409-417.

10. Нариманов Н.Р. Геодинамические аспекты формирования осадочного чехла Южно-Каспийской впадины // Геология нефти и газа. - 2003. - № 6. - С. 26-31.

11. Артюшков Е.В. Образование Южно-Каспийской впадины в результате фазовых переходов в нижней части континентальной коры // Доклады Российской Академии Наук.- 2007. Т. 416. - № 5. - С. 647-652.

12. Нариманов Н.Р. Геодинамическая обстановка обрамления Южно-Каспийской мегавпадины // Геолог Азербайджана. 2005. - № 10. - C. 26-32.

13. Narimanov A.A. The petroleum systems of the South Caspian Basin // Basin Modelling: Advanced Application. - 1993. - Amsterdam. NPF Special Publication 3. - P. 599-608. URL:
http://www.akifnarimanov.com/akif/extdocs/PetroleumSystemsOf SouthCaspianBasis.pdf (дата обращения 12.12.2019).

14. Deep petroleum occurrences in the Lower Kura Depression, South Caspian Basin, Azerbaijan: an organic geochemical and basin modelling study / S. Inan, M.N. Yalcin, I.S. Guliev, K. Kuliev, A.A. Feizullayev // Marine and Petroleum Geology. - 1997. V. 14. - № 7-8. - P. 731-762.

15. Нариманов Н.Р., Халилов Н.О., Хыдырова Р.А. Геотемпературное условие и потенциал нефтегазообразования Пираллахи-Келькорского прогиба // Азербайджанское Нефтяное Хозяйство. - 2002. - № 9. - С. 7-11.

16. Нариманов Н.Н. Влияния геодинамических процессов на нефтегазообразование в Южно-Каспийской впадине // Азербайджанское Нефтяное Хозяйство. - 2008. - № 8. - С. 13-18.

17. Jackson J., Priestley K., Allen M. Active tectonics of the South Caspian Basin // Geophysical Journal International. - 2002. V. 148. - Iss. 2. - P. 214-245.

18. Салманов А.М., Сулейманов А.М., Магеррамов Б.И. Палеогеология нефтегазоносных районов Азербайджана. - Баку: Mars Print, 2015. $-470 \mathrm{c}$.

19. Onset of subduction as the cause of rapid Pliocene-Quaternary subsidence in the South Caspian basin / M.B. Allen, L. Anderson, S. Jones, A. Ismail-Zadeh, M. Simmons // Geology. - 2002. V. 30. - № 9. - P. 775-778.

20. Геотемпературные условия нефтегазоносности мезокайнозойского комплекса Южно-Каспийского бассейна / К.Н. Каграманов, М.С. Бабаев, С.Г. Шпырко, Х.З. Мухтарова // Геофизический журнал. Инст. Геофизики им. С.И. Субботина НАН Украины. - 2019. - № 5 (42). - С. 222-234.

21. Vahabov U.G. About the structure stages and plans of the Azerbaijan section of South Caspian Basin // Conference Proc. 74th EAGE Conference and Exhibition incorporating. EUROPEC, 2012. - P. 293-302. URL: https://www.earthdoc.org/content/serial/2214-4609 (дата обращения 12.12.2019).

Поступила: 18.12 .2019 2.

\section{Информация об авторах}

Myxтарова X.3., кандидат геолого-минералогических наук, доцент кафедры геологии нефти и газа Азербайджанского Государственного университета нефти и промышленности.

Насибова Г.Д., кандидат геолого-минералогических наук, доцент кафедры геологии нефти и газа Азербайджанского Государственного университета нефти и промышленности. 


\title{
UDC 553.98(479.24): 550.8.072
}

\section{OIL AND GAS POTENTIAL OF THE KHALI-NEFT DASHLARY ANTICLINE ZONE IN RELATION TO ITS PALEOTECTONIC SETTINGS}

\author{
Khuraman Z. Mukhtarova1, \\ mukhtarova.khuraman@mail.ru \\ Gultar J. Nasibova ${ }^{1}$ \\ gultar_nasibova_1@yahoo.com \\ ${ }^{1}$ Azerbaijan State Oil and Industry University, \\ 34, Azadlig avenue, Baku, AZ1010, Azerbaijan.
}

\begin{abstract}
Relevance. The study was carried out in Absheron oil and gas region, which is one of the productive in Azerbaijan. The aim of implemented researches consists in increasing hydrocarbon production which is achieved by identifying new oil and gas reservoirs within deposit. From this point of view reservoirs associated with anticlinal and non-anticlinal types of traps within the Khali-Neft Dashlari anticlinal belt were identified. The approach was based on section Paleogene-Miocene sediments, the identification of reservoirs was associated with anticlinal and non-anticlinal types of traps. Such approach has an important practical feature and this will definitely play an important role in increasing oil and gas production in the republic. Our studies were carried out according to the criteria determining oil and gas potential, such as geothermal, lithofacial, tectonic, paleotectonic, etc. Estimations and attempts to identify new reservoirs were carried out along the stratigraphic profile of the Paleogene-Miocene and Pliocene ages.

The main aim of the research is to determine, from geothermal aspect, present location of the productive series deposits within the oil and gas generation zone and, in this relation, clarify prospectivity of the zone, as well as to investigate the prevalence of non-anticline traps in association with paleotectonic properties and syndepositional evolution of the zone.

Research area: individual structures representing Khali-Neft Dashlari anticline zone, Lower productive series suites.

Methods. Changes in total thickness and sandiness of the productive series deposits within the structures under investigation were analyzed at local and regional scales, the corresponding diagrams reflecting the patterns of changes in thickness and sandiness of individual suites were plotted. Paleoprofiles reflecting the paleotectonic evolution of the structures of the Khali-Neft Dashlari anticline zone were constructed.

Results. Construction of the deposition rate diagram and, in this regard, the data analysis, study of the paleotemperature environment of the Pirallahi-Kelkor depression and the analysis performed allow us to determine the terms of staying of both the productive series and the underlying Miocene, Paleogene and Mesozoic sediments within the main oil and gas formation zone, as well as to compare the major migration stages with the structure formation periods within a given territory. The results of all studies carried out in this direction allow us to state that the research area and its environs are also promising from the point of view of oil and gas potential.
\end{abstract}

\section{Key words:}

Thickness, sandiness, prospectivity, zone, structure, deposit, paleoprofile, productive series, paleotectonics, oil, gas.

\section{REFERENCES}

1. Zonenshayn L.P., Kuzmin M.I., Natapov L.M. Tektonika litosfernykh plit territorii SSSR [Lithospheric plate tectonics of the USSR]. Moscow, Nedra Publ., 1990. 328 p.

2. Narimanov A.A. Concept on the formation of the oil and gas fields in the South Caspian Basin. Transaction of the international Academy of Science, 2005-2006, vol. 2, pp. 483-499.

3. Mukhtarova K.Z., Nasibova G.J. Hydrocarbon potential of possible non-standard type pools (lithologically confined) of the Khali-Kapaz anticline belt in connection with its history of geologic evolution. Geologiya, geofizika i razrabotka neftyanykh $i$ gazovykh mestorozhdeniy, 2018, no. 10, pp. 8-20. In Rus.

4. Rakhmanov I.P. Gryazevye vulkany $i$ ikh znacheniya v prognozirovanii neftegazonosnosti nedr [Mud volcanoes and their importance in predicting hydrocarbon potential of the depths]. Moscow, Nedra Publ., 1987. 271 p.

5. Mukhtarova K.Z., Nasibova G.J. Perspektivniye neftegazonosnye struktury Absheronskogo arkhipelaga YuKV i osnovnoe napravlenir ikh dalneyshikh issledovaniy [Prospective oil and gas bearing structures of the Absheron archipelago of the SCB and major trends of their further study]. International Scientific and Practical Conference. Worldsclence. Abu-Dhabi, UAE, August, 2016. pp. 32-39.

6. Mukhtarova K.Z., Nasibova G.J. Oil and gas content perspectives of potential non-standard pool types (lithologically confined) of Khali-Kapaz anticlinal belt in connection with its geological development history. National Science Review, December, 2017, vol. 4, Iss. 4, pp. 1397-1416.
7. Guliyev I.S., Mamedov P.Z., Feyzullayev A.A., Huseynov D.A., Kadirov F.A., Aliyeva E.H., Tagiyev M.F. Hydrocarbon systems of the South Caspian basin. Baku, Nafta-Press, 2003. 206 p.

8. Mukhtarova K.Z., Nasibova G.J. Paleotectonic environment of formation of structures in the South Caspian basin and oil and gas prospectives of the non-anticline traps. Geolog Azerbaijana. Nauchniy bulleten Azerbaijanskogo Obshestva Neftyanikh Geologov, 2017, no. 21, pp. 82-93.

9. Feyzullayev A.A., Guliyev İ.S., Tagiyev M.F. Source potential of the Mesozoic-Cenozoic rocks in the South Caspian Basin and their role in forming the oil accumulations in the Lower Pliocene reservoirs. Petroleum Geoscience, 2001, vol. 7 (4), pp. 409-417.

10. Narimanov N.N. Geodynamic aspects of formation of the sedimentary mantle of the South Caspian depression. Geologiya nefti i gaza, 2003, no. 6, pp. 26-31. In Rus.

11. Artyushkov Y.B. Formation of the South Caspian depression as a result of phase transitions in the lower part of the continental crust. Dokladi Rossiyskoy Akademii Nauk, 2007, vol. 416, no. 5, pp. 647-652. In Rus.

12. Narimanov N.N. Geodynamic settings of the borders of the South Caspian megadepression. Geolog Azerbaijana, 2005, no. 10, pp. 26-32.

13. Narimanov A.A. The petroleum systems of the South Caspian Basin. Basin Modelling: Advanced Application. 1993. pp. 599-608. Available at: http://www.akifnarimanov.com/akif/extdocs/PetroleumSystemsOfSouthCaspianBasis.pdf (accessed 12 december 2019).

14. Inan S., Yalcin M.N., Guliev I.S., Kuliev K., Feizullayev A.A. Deep petroleum occurrences in the Lower Kura Depression, South Caspian Basin, Azerbaijan: an organic geochemical and basin 
modelling study. Marine and Petroleum Geology, 1997, vol. 14, no. 7-8, pp. 731-762.

15. Narimanov N.N., Khalilov N.O., Khidirova R.A. Geotemperature environment and oil and gas generation potential of the PirallahiKelkor depression. Azerbayzhanskoe Neftyanoe Khozyaystvo, 2002, no. 9 , pp. 7-11.

16. Narimanov N.N. Impact of geodynamic processes upon oil and gas generation in the South Caspian basin. Azerbayzhanskoe Neftyanoe Khozyaystvo, 2008, no. 8, pp. 13-18.

17. Jackson J., Priestley K., Allen M. Active tectonics of the South Caspian Basin. Geophysical Journal International, 2002, vol. 148, Iss. 2, pp. 214-245.

18. Salmanov A.M., Suleymanov A.M., Magerramov B.I. Paleogeologiya neftegazonosnykh rayonov Azerbaijana [Paleogeology of oil and gas regions of Azerbaijan]. Baku, Mars Print, 2015. $470 \mathrm{p}$.
19. Allen M.B., Anderson L., Jones S., Ismail-Zadeh A., Simmons M. Onset of subduction as the cause of rapid Pliocene-Quaternary subsidence in the South Caspian basin. Geology, 2002, vol. 30, no. 9 , pp. $775-778$.

20. Kagramanov K.N., Babayev M.S., Shpirko, Mukhtarova K.Z. Geothermal conditions of hydrocarbon prospectivity of MesoCenozoic formations in South Caspian basin. Geofizicheskiy jurnal. Inst. Geofiziki im. S.I. Subbotina, 2019, no. 5 (42), pp. 222-234. InRus.

21. Vahabov U.G. About the structure stages and plans of the Azerbaijan section of South Caspian Basin. Conference Proc. $74^{\text {th }}$ EAGE Conference and Exhibition incorporating. EUROPEC, 2012. pp. 293-302. Available at: https://www.earthdoc.org/ content/serial/2214-4609 (accessed 12 December 2019).

Received: 18 December 2019.

\section{Information about the authors}

Khuraman Z. Mukhtarova, Cand. Sc., associate professor, Azerbaijan State Oil and Industry University.

Gultar J. Nasibova, Cand. Sc., associate professor, Azerbaijan State Oil and Industry University. 